\title{
ANALISIS USAHATANI KOPI DI DESA PIRIAN TAPIKO KECAMATAN TUTAR KAB.POLEWALI MANDAR.
}

\author{
Rahmaniah HM.,SP, M.Si \\ rahmaniah_nia44@yahoo.co.id
}

\begin{abstract}
Abstrak
Pengembangan kopi di Kabupaten Polewali Mandar dari tahun ke tahun semakin berkembang yang ditandai dengan perkembangan luas lahan dan produksi serta jenis kopi yang dikembangkan. Peningkatan produksi tersebut dapat dicapai dengan adanya usaha peningkatan produktivitas tanaman per hektar dengan jalan ekstensifikasi dan intensifikasi melalui rehabilitasi, peremajaan, dan penggunaan faktor produksi yang semakin baik. Salah satu daerah pengembangan kopi di Kabupaten Polewali Mandar salah satunya adalah Desa Pirian tapiko Kecamatan Tutar. Populasi dalam penelitian ini adalah petani kopi yang ada di Desa Pirian Tapiko sebanyak 283 orang. pengambilan sampel dilakukan dengan mempergunakan metode acak sederhana (simple random sampling) di mana setiap petani memiliki kesempatan yang sama untuk dipilih, dan dipilih 30 orang petani sebagai sampel dari sejumlah populasi. Untuk menganalisa digunakan rumus analisis pendapatan. Besarnya pendapatan petani kopi di Desa Pirian tapiko sebesar Rp 11. 322.042,50 dimana R/C sebesar 1,72 hal ini menunjukkan bahwa usahatani kopi tersebut layak untuk dikembangkan, dan memiliki prospek yang menjanjikan.
\end{abstract}

\section{Keyword : kopi robusta, analisis pendapatan, efisiensi biaya dan pendapatan}

\section{LATAR BELAKANG}

Kopi merupakan salah satu hasil komoditi perkebunan yang memiliki nilai ekonomis yang cukup tinggi di antara tanaman perkebunan lainnya dan berperan penting sebagai sumber devisa negara. Kopi tidak hanya berperan penting sebagai sumber devisa melainkan juga merupakan sumber penghasilan bagi tidak kurang dari satu setengah juta jiwa petani kopi di Indonesia. Keberhasilan agribisnis kopi membutuhkan dukungan semua pihak yang terkait dalam proses produksi kopi pengolahan dan pemasaran komoditas kopi. Upaya meningkatkan produktivitas dan mutu kopi terus dilakukan sehingga daya saing kopi di Indonesia dapat bersaing di pasar dunia (Rahardjo, 2012).

Pengembangan kopi di Kabupaten Polewali Mandar dari tahun ke tahun semakin berkembang yang ditandai dengan perkembangan luas lahan dan produksi serta jenis kopi yang dikembangkan. Peningkatan produksi tersebut dapat dicapai dengan adanya usaha peningkatan produktivitas tanaman per hektar dengan jalan 
ekstensifikasi dan intensifikasi melalui rehabilitasi, peremajaan, dan penggunaan faktor produksi yang semakin baik. Ada berapa kecamatan yang merupakan pengembang kopi terbesar di Kabupaten Polewali Mandar salah satunya adalah Kecamatan Tutar. Berdasarkan data dari BalaiPusat Statistik (BPS) Polewali Mandar bahwa pada tahun 2015 luas areal perkebunan kopi di Kecamatan Tutar mencapai 650,51 Ha, dengan produksi kopi mencapai 167.76 Ton. Berikut luas lahan dan produksi kopi di Desa Pirian Tapiko Kecamatan Tutar Kabupaten Polewali Mandar.

Tabel 1. Luas Lahan dan Jumlah Produksi Kopi di Kecamatan Tutar Kab. Polewali Mandar, dalam kurun waktu 2010 - 2015.

\begin{tabular}{ccccc}
\hline No. & Tahun & $\begin{array}{c}\text { Luas areal } \\
(\mathbf{H a})\end{array}$ & $\begin{array}{c}\text { Jumpah } \\
\text { Produksi (ton) }\end{array}$ & $\begin{array}{c}\text { Produktifitas } \\
\text { (kg/ha) }\end{array}$ \\
\hline 1 & 2010 & 682,50 & 58,88 & 882,71 \\
2 & 2011 & 640,51 & 59,62 & 930,82 \\
3 & 2012 & 640,51 & 167,76 & 2619,16 \\
4 & 2013 & 635,51 & 167,76 & 2639,77 \\
5 & 2014 & 641,01 & 167,82 & 2616,02 \\
6 & 2015 & 650,51 & 167,72 & 2578,90 \\
\hline
\end{tabular}

Sumber : BPS Polewali Mandar, 2017

Berdasarkan tabel 1 di atas dapat dilihat bahwa luas lahan pertanaman petani cenderung mengalami peningkatan berbeda dengan jumlah produksi yang mengalami peningkatan sangat signifikan pada tahun 2012 di mana mengalami peningkatan 35\% dari tahun sebelumnya sedangkan luas lahan tetap. Berdasarkan survey awal di lokasi penelitian diperoleh informasi bahwa permasalahan yang dihadapi petani kopi di daerah ini diantaranya produktivias yang rendah yang disebabkan karena tingkat keterampilan dan pengetahuan petani yang masih rendah, utamanya dalam hal budidaya kopi sesuai teknis sehingga penggunaan lahan belum optimal. Selain itu, masih banyak lahan yang masih kosong dan belum optimal. Permasalahan lain yang dihadapi adalah sarana dan prasarana perhubungan yakni belum memadainya sarana perhubungan sampai ke pelosok sehingga tidak dapat menjangkau semua daerah sentra poroduksi dan sangat mempengaruhi usaha pemasaran hasil perkebunan kopi petani sekaligus mempengaruhi tingkat harga yang diterima oleh petani. Berdasarkan hal tersebut di atas maka penting melakukan penelitian tentang Analisa Pendapatan Petani Kopi di 
Desa Pirian Tapiko di Kecamatan Tutar Kabupaten Polewali Mandar. Adapun tujuan dari penelitian ini adalah Mengetahui besarnya pendapatan usahatani kopi di Desa Pirian Tapiko Kecamatan Tutar Kabupaten Polewali Mandar.

\section{METODE PENELITIAN}

Populasi dalam penelitian ini adalah petani kopi yang ada di Desa Pirian Tapiko Kecamatan Tutar Kabupaten Polewali Mandar yaitu sebanyak 283 orang. pengambilan sampel dilakukan dengan mempergunakan metode acak sederhana (simple random sampling) di mana setiap petani memiliki kesempatan yang sama untuk di pilih (Winartha, 20106) dan dipilih 30 orang sebagai sampel dari sejumlah populasi.

Untuk menjawab tujuan penelitian (1) maka digunakan secara kuantitatif rumus:

$$
\begin{aligned}
\pi=\mathrm{TR} & -\mathrm{TC} \\
\text { Ket }: \pi \quad & =\text { Pendapatan } \\
\mathrm{TR} & =\text { Total penerimaan } \\
\mathrm{TC} & =\text { Total biaya }
\end{aligned}
$$

\section{HASIL DAN PEMBAHASAN}

\section{Analisis pendapatan Kopi}

Analisis pendapatan usahatani kopi pada lokasi penelitian dilakukan berdasarkan data yang diperoleh dari petani responden sebanyak 30 orang. Penerimaan usahatani diperoleh dari hasil kali jumlah produksi dengan harga produk yang diterima oleh responden, sedangkan pendapatan diperoleh dari selisih antara penerimaan dengan total biaya usahatani yang dikeluarkan. Berikut disajikan rata-rata pendapatan petani kopidi Desa Pirian Tapiko Kecamatan Tutar sebagai berikut;

Tabel 2. Rata-rata Produksi, Penerimaan, Biaya dan pendapatan Petani Kopi di Desa Pirian Tapiko,2017

\begin{tabular}{ccccccc}
\hline $\begin{array}{c}\text { Jumlah } \\
\text { responden }\end{array}$ & $\begin{array}{c}\text { Luas lahan } \\
(\mathbf{H a})\end{array}$ & $\begin{array}{c}\text { Produksi } \\
(\mathbf{K g})\end{array}$ & $\begin{array}{c}\text { Harga Jual } \\
(\mathbf{R p})\end{array}$ & $\begin{array}{c}\text { Penerimaan } \\
(\mathbf{R p})\end{array}$ & $\begin{array}{c}\text { Biaya } \\
(\mathbf{R p})\end{array}$ & $\begin{array}{c}\text { Pendapatan } \\
(\mathbf{R p})\end{array}$ \\
\hline $\mathbf{3 0}$ & 1.7 & 1.246 & 21.730 & 27.075 .580 & $15.753 .537,50$ & $11.322 .042,50$ \\
\hline
\end{tabular}

Sumber: Data primer setelah diolah, 2017

Berdasarkan tabel diatas terlihat bahwa setelah dilakukan analisa pendapatan menunjukkan bahwa rata-rata pendapatan yang diperoleh petani kopi robusta sebesar Rp11.322.042,50 berarti bahwa adanya keuntungan yang diperoleh FORUM DOSEN INDONESIA - DPD Sulawesi Barat - 2017 
masing-masing petani responden dalam berusahatani kopi tergantung dari harga kopi kering per satuan dimana saat ini harga rata-rata sejumlah

$\operatorname{Rp} 21.730,-$ dan harga sewaktu-waktu berubah tergantung sejauhmana mana permintaan pasar. Selain itu, tingkat produksi juga masih tinggi bila tidak diimbangi dengan pemberian sarana produksi seperti pupuk, pestisida dan bibit yang unggul. Berdasarkan hasil penelitian bahwa semua petani sampel tidak memberikan pupuk selain pupuk kandang dimana harga pupuk kandang masih cukup murah yakni Rp $10.000,-/ 100 \mathrm{Kg}$ atau bahkan tidak ternilai oleh petani karena sebagian petani juga merupakan peternak kambing. Pemberian pestisida juga diperuntukkan bagi rumput liar yang ada disekitaran tanaman kopi dan hama penyakit pun masih kurang, hal ini disebabkan karena kopi di Desa Pirian Tapiko berada pada kondisi ideal tumbuhnya kopi robusta dan tidak tersentuh dengan penanganan kimiawi yang berlebihan serta daerah tersebut masih dalam kondisi tingkat kesuburan tinggi dan ekosistem masih alami sehingga bibit yang digunakan pun masih merupakan bibit yang dari awal pertanaman. Penggunaan tenaga kerja juga hanya menggunakan tenaga kerja dalam keluarga baik untuk penanaman, perawatan maupun panen karena daerah ini masih menjunjung tinggi gotong royong dan begitupun dengan kegiatan kebun dilakukan secara bersama-sama terutama saat panen dan pascapanen sehingga biaya-biaya produksi dengan sendiri dapat dikurangi akan tetapi nilai tenaga kerja (HOK) tinggi karena dilakukan oleh keluarga secara bersama-sama. Berikut adalah rata-rata penggunaan biaya produksi usahatani kopi di Desa Pirian Tapiko, dapat dilihat pada tabel 3:

Tabel 3 Rata-Rata Penggunaan Biaya Usaha Tani Kopi Di desa Pirian Tapiko,2017

\begin{tabular}{|l|l|l|c|c|}
\hline No. & \multicolumn{1}{|c|}{ Komponen } & \multicolumn{1}{|c|}{ Jumlah } & $\begin{array}{c}\text { Harga Satuan } \\
(\text { Rp) }\end{array}$ & Jumlah (Rp) \\
\hline 1. & Biaya variabel & & & \\
\hline & $\bullet$ Bibit & $1.640 \mathrm{Phn}$ & 2.700 & $4.428 .000,-$ \\
& $\bullet$ Pupuk Kandang & $420 \mathrm{~kg}$ & $10.000,-/ 100 \mathrm{Kg}$ & $420.000,-$ \\
& $\bullet$ Pestisida & & 525.000 \\
& o Gramoxon & & & \\
& o Kanof & & & \\
& Tenaga Kerja & & & $1.352 .500,-$ \\
& $\bullet$ Pengolahan lahan & 25 HOK & 54.100 & $1.109 .050,-$ \\
& Penanaman & $20,5 \mathrm{HOK}$ & 54.100 & $453.087,50$ \\
\hline
\end{tabular}




\begin{tabular}{|c|c|c|c|c|}
\hline & $\begin{array}{l}\text { - Pemupukan } \\
\text { - Penyemprotan } \\
\text { Pestisida } \\
\text { - Pemangkasan } \\
\text { - Panen } \\
\text { - Pascapanen }\end{array}$ & $\begin{array}{l}8,25 \mathrm{HOK} \\
5,625 \mathrm{HOK} \\
25,375 \mathrm{HOK} \\
38,75 \mathrm{HOK} \\
56 \mathrm{HOK} \\
\end{array}$ & $\begin{array}{l}54.100 \\
54.100 \\
54.100 \\
54.100 \\
54.100 \\
\end{array}$ & \begin{tabular}{l}
\multicolumn{1}{c}{$446.325,-$} \\
$304.312,50$ \\
\\
$1.372 .787,50$ \\
$2.096,375$ \\
3.029 .600
\end{tabular} \\
\hline & Jumlah (Vc) & & & $15.537 .037,50$ \\
\hline 2. & Biaya Tetap & & Nilai Penyusutan & \\
\hline & $\begin{array}{l}\text { - Pajak } \\
\text { - Biaya Penyusutan } \\
\text { alat }\end{array}$ & & & $\begin{array}{r}82.000 \\
134.500\end{array}$ \\
\hline \multicolumn{3}{|c|}{ Jumlah (Fc) } & & 216.500 \\
\hline \multicolumn{4}{|c|}{ Jumlah Keseluruhan } & $15.753 .537,50$ \\
\hline
\end{tabular}

\section{Sumber: Data Primer Setelah Diolah, 2017}

Tabel 3 tersebut diatas terlihat bahwa biaya rata-rata yang dikeluarkan masing-masing responden seperti biaya variabel yaitu Rp15.537.037,50,sedangkan biaya tetap Rp 216.500 dan jumlah total rata-rata pengeluaran masingmasing responden yaitu sebesar Rp15.753.537,50,- Untunk menghitung jumlah pendapatan maka digunakan rumus :

$$
\begin{aligned}
& \Pi=\mathrm{TR}-\mathrm{TC} \\
& =\text { Penerimaan }- \text { Total biaya } \\
& =27.075 .580-15.753 .537,50 \\
& =11.322 .042,50
\end{aligned}
$$

Maka rata-rata pendapatan usahatani kopi di Pirian Tapiko sebesar Rp11.322.042,50,- .Berdasarkan hasil penelitian yang dilakukan terhadap petani kopi di Desa Pirian tapiko, maka:

$$
\begin{aligned}
& \mathrm{R} / \mathrm{C}=\text { Penerimaan } / \text { Total biaya } \\
& \mathrm{R} / \mathrm{C}=27.075 .580 / 15.753 .537,50 \\
& \mathrm{R} / \mathrm{C}=1,72
\end{aligned}
$$

Hal ini menunjukkan bahwa, nilai R/C ratio lebih besar dari satu yaitu sebesar 1,72 hal ini berarti bahwa usahatani kopi menguntungkan dan layak untuk diusahakan. Selanjutnya nilai $\mathrm{R} / \mathrm{C}$ ratio sebesar 1,72 menunjukkan bahwa untuk setiap peningkatan biaya pengeluaran dalam berusahatani kopi sebesar $\quad \mathrm{Rp}$ 100,- maka penerimaan akan meningkat sebesar Rp.172,- atau setiap Rp.1.000.000,-yang diinvestasikan petani kopi robusta akan memperoleh penerimaan sebesar Rp 1.720.000,-. Soekartawi (2005) mengemukakan bahwa 
kriteria keuntungan dengan indikator R/C > 1 dianggap menguntungkan dan layak diusahakan dan dapat disimpulkan bahwa dengan nilai $\mathrm{R} / \mathrm{C}$ rasio sebesar 1,72 ini mengiindikasikan bahwa usahatani kopi robusta pada lokasi penelitian layak untuk diusahakan, karena ini mengindikasikan pula bila usahatani kopi ini memiliki potensi untuk dikembangkan kedepan.

\section{KESIMPULAN DAN SARAN}

\section{Kesimpulan}

Berdasarkan hasil pembahasan maka ditarik kesimpulan bahwa: Besarnya pendapatan petani kopi di Desa Pirian tapiko sebesar Rp 11.322.042,50,- dan R/C sebesar 1,72 hal ini menunjukkan bahwa usahatani kopi tersebut layak untuk dikembangkan, dan memiliki potensi untuk dikembangkan kedepan.

\section{Saran}

1. Sebaiknya petani menggunakan sarana produksi berupa pemupukan yang sesuai teknis, pemeliharaan lebih intensif sehingga hasil lebih optimal.

2. Sebaiknya petani melakukan pertemuan rutin kelompok tani dengan memanfaatkan fasilitas dari penyuluh pertanian lapangan agar dapat bekerja sama dan berbagi ilmu tentang usahatani.

3. Kopi ini memiliki potensi pasar yang cukup baik sehingga dukungan dari pemerintah sangat diharapkan dengan membuka pasar kemitraan dan dapat melakukan pendamping dan pelatihan petani yang lebih baik.

\section{DAFTAR PUSTAKA}


Rahardjo, Pudji. 2012. Panduan Budidaya dan Pengolahan Kopi Arabika dan Robusta. Penebar Swadaya. Jakarta

Badan Pusat Statistik, Kabupaten Polewali Mandar dalam angaka. 2015.

Najiyati dan Danarti. 2007. Kopi budidaya dan penanganan pasca panen Cet.12, Penebar Swadaya , Jakarta 2001.

Mubyarto, Pengantar Ekonomi Pertanian, edisi ke III, LP3ES, Jakarta, 2006.

Mosher, A. T. Menggerakan dan Membangun Pertanian, Syarat-syarat Pokok pembagunan dan ModernisasiCet 8, Yasaguna, 2003.

Palita, Anthon Pengembangan Komoditas Kopi dan Peluang Eksplor di SULSEL, Makassar 2007.

Raharjo, Prospek Pengembangan dan Peningkatan Produksi Tanaman Kopi di Kecamatan Alla, Kabupaten Enrekang, Makassar 2012.

Soekarwati, Teori Eknomi Produksi, dengan pokok bahasan Cobb Dauglas, Cet 3. PT. Raja Garfindo, Jakarta 2005.

Wiratha, 2006. Metode Penelitian. Penerbit Ghalia Indonesia. Jakarta 2002.

Mawardi, pengembangan kopi Indonesia ekspor kenegara lainl, Penerbit Angkasa Bandung 2008. 